\title{
Conatus, de Belén Blesa: una poética de lo Cotidiano
}

\author{
CARMen María LóPez LóPEZ \\ Universidad Católica San Antonio de Murcia
}

Obra inclasificable, rara avis en el panorama editorial más reciente es Conatus $^{1}$ de Belén Blesa, licenciada en Psicología y Doctora en Filosofía, actualmente profesora e investigadora de la Universidad Católica de Murcia. La autora se decanta aquí por un tono íntimo y personal, muy distinto al que anima Bestiarium curriculum. Meditaciones acerca del acontecimiento (en la academia) ${ }^{2}$. Como expresa Antonio Candeloro $^{3}$, si Bestiarium curriculum era un libro donde se unían los tres polos de «la filosofía, el arte y la reflexión sobre el mundo universitario» con el fin de «desburocratizar la educación» (2019: 319) para significar precisamente la crisis de la universidad y trazar una radiografía y diagnóstico personal del sistema educativo, Conatus descubre la vertiente más íntima, introspectiva y visceral de la autora. La fuerza centrífuga de Bestiarum deviene centrípeta en Conatus, porque esta es una obra que transita por otras regiones del pensamiento, más acotadas pero más volubles, menos definidas, de mayor abstracción, acaso más trascendentes. Los temas e ideas acortan su ratio para proyectarse en el individuo; y de la reflexión sobre las Humanidades y el sentido de la enseñanza se desciende al yo, motor que las alienta y se sitúa en el centro. El yo del libro se construye a imagen y semejanza de quien escribe, en un ensamblaje entre creador y criatura. La mirada y conocimiento del mundo orbitan en torno al yo-cognoscente, quien proyecta su visión sobre la letra impresa, y así texto y autor quedan unidos indeleblemente.

En este sentido, la mirada literaria de Belén Blesa no dista mucho de aquella que proyectara Montaigne ${ }^{4}$ en sus Ensayos: essais, pruebas, esbozos, tentativas. Esta afinidad creadora puede cotejarse en los textos-prólogo donde prevalece un propósito similar: «yo mismo soy la materia de mi libro» (2004: 35); «Conatus (esta obra) es

\footnotetext{
${ }^{1}$ Belén Blesa, Conatus, Salamanca, Amarante, 2020.

${ }^{2}$ Belén Blesa, Bestiarium Curriculum. Meditaciones acerca del acontecimiento (en la academia), Salamanca, Amarante, 2019.

${ }^{3}$ Antonio Candeloro, «Bestiarium Curriculum. Meditaciones acerca del acontecimiento (en la academia)», Educatio Siglo XXI, 2019, vol. 37, n. ${ }^{\circ}$ 2, págs. 317-320.

${ }^{4}$ Michel de Montaigne, Ensayos completos, Madrid, Cátedra, 2004.
} 
conatus, no puedo definirla ni decir nada de ella por referencia a otra cosa. Gestos vitales, literarios y, tal vez, más poesía que fotografía en la imagen, como maneras de perseverar. Diría que es una poética de lo insignificante donde he encontrado verdades y, con ellas, un punto de luz» (2020: 7) A través de una prosa sencilla, Belén conquista las regiones de lo nimio, el canto hacia las cosas cotidianas que la fuerza de la costumbre automatiza pese al deslumbramiento que debieran suscitar. Con los ojos gastados de mirar el mismo paisaje, la autora fotografía y escribe estampas de lo cotidiano. Redescubre así una doble vertiente del lenguaje: la verbal y la visual, que no son opuestas, como la tradición secular nos ha querido hacer creer desde Platón, sino complementarias; y lo son precisamente en virtud de una armonía entre lo que la foto muestra y la palabra dice. Los textos, brevísimos, incluyen fotografías del archivo personal de la autora. Las imágenes fotográficas suscitan pensamientos y las reflexiones dotan de sentido a los paratextos visuales. Palabras e imágenes se conforman como vasos comunicantes de una potencia superior (el pensamiento que las alumbra) y que ha cristalizado en diferentes modos expresivos.

Tampoco es baladí que para titular su libro Belén Blesa haya elegido el término conatus. Conociendo su formación y afinidades electivas, podríamos pensar que la deuda es más filosófica que poética e incluso vital. Sin embargo, cuando el lector emprende la lectura se da cuenta de que aquí la palabra conatus descarta el sentido de trascendencia con que se había orlado en la historia de la filosofía, para ser sencillamente tentativa, intento, esbozo, y nada más. Nada más y nada menos, porque las elipsis, el estilo sentencioso y la tendencia a la brevedad encubren un mensaje otro, oculto, que está detrás de lo que las palabras dicen, y es ahí donde radica la fuerza germinal de sus escritos. El resultado estético es una obra de inusitada rareza, indómita, genuina. En ella prevalece el principio de extrañamiento, la repulsión hacia lo estandarizado, la mirada reacia al academicismo.

Otro de los enigmas del libro se encuentra en el punto de indeterminación al considerar qué sea, qué pueda ser o cómo pueda ser catalogada esta obra. ¿Reflexiones vitales? ¿Aforismos? ¿Estampas cotidianas? ¿Poesía en prosa? ¿Prosa poética? ¿Un breviario filosófico? ¿Meditaciones sobre la vida? Conatus quizá comparta un poco de todas ellas, sin ser sensu stricto ninguna. ¿A qué género literario podría adscribirse, por ejemplo, el texto que inaugura la obra? El bellísimo «Púas para clavar el amor» nace a partir de una conversación en una ferretería donde la autora se pregunta qué púas son más propicias para clavar una nota de amor. Lo valioso es que pese a no poder catalogar estos textos todavía siguen siendo bellos. En ningún caso se sacrifica la verdad por honor a la belleza, sino al contrario: es el cuidado formal el aura que envuelve estos pensamientos que también son certezas. 
Otras veces una foto revela la sombra de la autora en bicicleta y crea así la sensación de velocidad, el vértigo de sentirse libre. Y de la bicicleta al paseo, emerge el flâneur que al caminar crea también su propia historia:

Hay calles que no necesitan un monumento destacado para crear contigo una historia. Si me voy de aquí echaré de menos este lugar cuando ha perdido toda su funcionalidad los domingos por la tarde. Me gustan los lugares cuando son otra cosa que aquello para lo que tienen que ser. Igual me pasa con las personas (2020: 16).

La visión del transeúnte por las calles desérticas evoca en el lector la sensación liberadora de caminar los domingos por espacios ausentes. Y también una actitud indómita de las cosas vaciadas de la funcionalidad habitual para la que fueron creadas. Contempladora de cada resquicio, por insignificante que pueda parecer, Belén Blesa se fija en la impersonalidad de la lluvia, el oficio de llover sin saber quién llueve en una marginalidad sin sujeto: «Llueve y no hay quién llueva. Nadie llueve, ni el cielo. Llueve». La escritura es sensitiva y así logra palpar lo vivo de las cosas: «Me gusta pasear después de la lluvia e ir bordeando con los dedos las hojas mojadas de la tupida madreselva. Todo es brillante» (2020: 18). Al leer nos parece que pudiéramos toca la lluvia, aproximarnos al tacto rugoso del tronco de un árbol, tener el mundo de las palabras de Conatus unido a nuestra piel.

Estos breves atisbos, por su intensidad y aspiración a lo bello, suelen desencadenar una emoción poética: «Amarillea la tarde en las manos» (2020: 20). Pero es poesía que no da respuestas, sino que suscita preguntas: «¿Qué universo hay en el otro que nos retiene durante segundos que son honduras de la vida?» (2020: 26). La respuesta nadie la sabe. La verdad ha sido expulsada. Lo inmediato es aquello que podemos sentir. Conatus es poesía del cuerpo y asombro ante los objetos: «Algo mágico es el objeto solitario» (2020: 24), escribe de la rueda de una bicicleta: «Objetos como ese permiten devenir infancia el mundo, participar de un universo animado fuera de toda utilidad, ajeno a cualquier servilismo» (2020: 24). Tampoco faltan apotegmas y sentencias filosóficas, reflexiones vitales: «En mucho tiempo solo he pensado una cosa que haya merecido la pena: Lo imprevisto de la muerte en qué sentido me afecta. Entonces, me sitúo y siento que puedo mejorar. Mejorar es vivir dándome cuenta de morir» (2020: 42). La autora recupera el gusto de hacer fotografías y escribir sobre las fotos, mirarlas desde uno y otro perfil y dejar que así broten las palabras alumbradas por la imagen y a la inversa: «Me detengo en una amapola enfurecida con gotas de agua. Es bella. Hago una foto con el móvil» (2020: 50). La visión de la amapola desencadena en la autora el impulso de tomar una fotografía: la mirada perpleja ante la belleza furiosa de la flor, y de ahí el sentimiento cuya contemplación 
despierta, con reminiscencias del poema que Sylvia Plath ${ }^{5}$ dedicara a los tulipanes: «Los tulipanes son, ante todo, demasiado rojos: me hieren» (2020: 30). La herida del color es más profunda que una herida de la que mana sangre. Sin embargo, en Conatus las amapolas no son estigma de enfermedad, sino esplendor de vida de estos seres desvalidos y muy poco proclives a las fotos:

Las amapolas son seres difíciles para la foto, suelen estar rodeadas de elementos poco atractivos cuyo fondo cuestiona su rojo esplendor. Cuando llego a casa, me recuesto sobre el sillón de rayas y consigo neutralizarlo, eso, el fondo. En la imagen, amapola llorando después de la furia. A mí también me sucede así (2020: 50).

En algunos textos el estilo aforístico descubre una mirada piadosa, sobrecogedora, cargada de amor. Así se aprecia en la meditación sobre el cuerpo-casa-corazón que habitamos, que nos habita, y que es de color rojo sangre. Alma y cuerpo, sombra y luz trazan la trayectoria emocional y cromática del libro: «Me gusta pensar que el alma sea oscura y requiera un cuerpo desde el que expresarse con claridad» (2020: 37). Quedan así perfilados los claroscuros del corazón, a los que el cuerpo dota de luz pues pone carne a la materia intangible del espíritu.

Entre reflexiones misceláneas y variopintas, hilvanadas todas ellas por el yo del cuerpo-casa-corazón que escribe, se filtran intuiciones sobre el proceso de la creación, atisbos de metaliteratura. En estos breves hallazgos se da cuenta de lo que para la autora sea el misterio del arte literario: «No era esto lo que quería escribir. Nunca lo ha sido. Pero hay algo irreverente y despótico cuando se escribe con fuego del bajo vientre. A veces escribo con la cabeza (estoy débil) o con el centro (estoy sensible) y, más abajo, el instinto» (2020: 52). La escritura también es de color rojo, porque su alumbramiento en potencia es similar al fuego y se localiza en el vientre. Se escribe con las vísceras, desde el centro de las entrañas. Y casi siempre a oscuras, en un proceso penoso que en nada se parece al resultado creativo. Como cantó César Vallejo ${ }^{6}$, todos los que escriben lo saben: «Todos saben... Y no saben / que la luz es tísica / y la Sombra gorda...» (2020: 42). Por eso nunca la luz es suficiente:

Deja la luz tenue, si acaso, apagada. ¡Qué verso más aislado! Sin embargo, no es un verso frustrado sino autónomo. No acepta nada más, lo escupe. Es una insinuación de paisaje, de ese que deseas y ves cuando los contornos fijos de las cosas se empiezan a desvanecer y, entonces, hay espacio donde imaginar. Cada espacio hace su política (2020:32).

\footnotetext{
${ }^{5}$ Sylvia Plath, Ariel, Madrid, Hiperión, 1995.

${ }^{6}$ César Vallejo, Poesía completa, Madrid, Alianza, 2006.
} 
Así la autora va conformando su particular poética del acto creativo: «Da igual, la escritura escribe lo que quiere» (2020: 52). Pone énfasis en el carácter inasible y escurridizo de las palabras. Escribimos no lo que queremos escribir, sino lo que la escritura quiere que escribamos. La escritura no se crea: se alumbra. Y es lo propio que se desprenda de todo lo accesorio. El arte es un ejercicio de restar, quitar la hojarasca, el velo de la realidad para aquilatar lo significativo de la vida. Vivir es «sentarse en medio de lo simple, parpadear el mundo» (2020: 20). El lenguaje de Conatus no subyuga la verdad por el don de la belleza, sino que destila belleza precisamente por ser verdad, por dejar pasar la luz como el cristal más transparente. Quedan así derruidas las antiguas murallas que separaban el discurso filosófico del pensamiento literario. Quedan así desmontados los falsos prejuicios que encumbraban la literatura para desprestigiar otras regiones de las artes visuales. Así como la fotografía, es la escritura. De la antigua escisión Conatus sale fortalecido a través de la palabra cuyo sustento esencial son las fotografías $\mathrm{y}$, por añadidura, las fronteras porosas del arte. Lo que queda después en el lector es una sensación de liviandad, de paz, de haberse acercado a una obra capaz de nombrar con sencillez y profundidad una orilla del mundo. Y también una gratitud: la del que encuentra consuelo más allá de la filosofía, en la literatura. 